\title{
POSTMORTEM DETECTION OF LIVER CHIMERISM AFTER ALLOGENEIC HEMATOPOIETIC STEM CELL TRANSPLANTATION IN ADULT MALE MICE
}

\author{
Dena M. Nagieb ${ }^{1}$, Somia H. Abd Allah ${ }^{2}$, Nermien A. Ibrahim ${ }^{1}$ and Hany A. Meleka ${ }^{1}$ \\ ${ }^{1}$ Department of Forensic Medicine \& Clinical Toxicology, Faculty of Medicine, Zagazig University, \\ Egypt. \\ ${ }^{2}$ Department of Biochemistry, Faculty of Medicine, Zagazig University, Egypt.
}

\begin{abstract}
Introduction: Postmortem personal identification is based on the extraction of deoxyribonucleic acid (DNA) from human remains or different human materials. There are some reports proving that various tissues may differ genetically and do not always have the DNA profile of the person from whom they originate due to mutation or chimerism. Aim of the work: The work aimed at the postmortem detection of the possible change in DNA fingerprint after allogeneic hematopoietic stem cell transplantation in liver tissue samples. Materials and Methods: One hundred twenty eight adult male mice weighing 25g. DNA fingerprint first was done from blood samples. After 3 months from interference, postmortem DNA fingerprinting was done again from liver tissue. Results: Fluorescent stem cells were detected postmortem in liver tissue of 30 mice by percentage of $93.75 \%$. The change in DNA profile was detected postmortem in 20 mice in liver tissue samples by a percentage of $62.5 \%$. Conclusion: DNA chimerism, after allogeneic hematopoietic stem cell transplantation, can be detected postmortem in the recipient's liver. Recommendations: It's recommended to study the postmortem detection of DNA chimerism in organs other than the liver to compare the percentage of chimerism detection.
\end{abstract}

Key words: Postmortem; Liver; Chimerism; Allogeneic Hematopoietic Stem Cell Transplantation.

\section{INTRODUCTION}

Dersonal identification for patients who have undergone allogeneic hematopoietic stem cell transplantation (HSCT) is considered a major challenge (Santurtún et al., 2017). Medicolegal identification of an unknown person consists of the comparing individualizing features from antemortem information with postmortem data from the unidentified corpse (Angelis et al., 2016). This is not only important for the criminal and civil legal proceedings, but also, for the ethical consequences and the human right of being buried with his/her own name and mourned by relatives after death (Cattaneo et al., 2010). Based on the hypothesis that all human body cells have a consistent DNA profile, different types of DNA-containing tissue and fluids can be used to find a match (Jacewicz et al., 2013).

Allogeneic hematopoietic stem cells transplantation (allo-HSCT) has been widely used to treat patients with several illnesses, but the biological materials of those recipients may cause problems in personal identification due to what is called "chimerism" (Li et al., 2014). Chimerism is defined in transplantation medicine as the coexistence ofcells of, both, donor and recipient origin (Ten Hove et al., 2007). In previous studies, blood, hair samples and buccal swabs are studied as sources of DNA profiling after hematopoietic stem cell transplantation (Hong et al., 2007; Zhou et al., 2011; Li et al., 2014; Chaudhary et al., 2015; Santurtún et al., 2017) The partial chimerism is detectable predominantly in the 
hematopoietic system developed by transfusion or transplantation of allogenic hematopoietic stem cells (Milde et al., 1999).

This experimental work aims at studying the possibility of postmortem detection in DNA chimerism in liver tissue, after allogeneic hematopoietic stem cell transplantation.

\section{MATERIALS AND METHODS}

\subsection{Sampling and experimental design}

This study was done after the acceptance of Institution Review Board (IRB) of faculty of Medicine, Zagazig University.

One hundred twenty eight adult male mice (32 mice in each group) weighing $25 \mathrm{~g}$ obtained from the animal house of faculty of Medicine, Zagazig University were included in the study.

The experiment was performed in accordance with the Guide for the care and use of laboratory animals.

Group I (Control group): It was divided into three subgroups: Group Ia, it was the negative control subgroup in which the mice didn't take any drugs. Group Ib, mice receive 2 intraperitoneal (i.p.) injections of Busulfan $(35 \mathrm{mg} / \mathrm{kg}) \quad 24$ hours apart, then Cyclophosphamide $(100 \mathrm{mg} / \mathrm{kg})$ intraperitoneal injection 24 hours after last Busulfan dose (Nevozhay \& Opolski, 2006) Group Ic, It was the control group injected with hematopoietic stem cell without immunosuppression.

Group II (Hematopoietic stem cell transplanted group):

Hematopoietic stem cell transplantation was done after immunosuppression. Mice recieved 2 i.p. injections of Busulfan $(35 \mathrm{mg} / \mathrm{kg}$ ) 24 hours apart before stem cell injection by 4 days, then cyclophosphamide $(100 \mathrm{mg} / \mathrm{kg})$ i.p. injection 24 hour after last Busulfan dose
(Nevozhay \& Opolski, 2006). Hematopoietic stem cell transplantation then done.

In all groups, DNA profile was done from blood before hematopoietic stem cell transplantation from all mice. Three months after interference, all mice will have DNA profile again done from postmortem liver tissue.

Blood samples: $0.5 \mathrm{ml}$ blood was collected from orbital sinus of mice in the 1.5 $\mathrm{ml}$ micro centrifuge tubes (Parasuraman et al., 2010). Postmortem tissue samples were taken by a surgical incision from the liver (Picazo MG \& García-Olmo, 2015).

\subsection{Hematopoietic stem cell transplantation}

Ten $\mathrm{ml}$ blood was isolated from donor mice by using ficoll gradient precipitation method.

Hematopoietic stem cells were separated using separating column to isolate Cd34 cell (HSC) from MSC the cultured in complete culture medium. After trypsinization, staining of cells was done by PKH26 red fluorescent cell linker. Then the cells were injected IV in the tail vein of the mice.

\subsection{Fluorescent microscopic examination}

Fixed liver tissue was sectioned into very thin (5 micrometers) sections using a microtome; the sections were examined under fluorescent microscope.

\subsection{Deoxyribonucleic acid profiling:}

Deoxyribonucleic acid extraction was done according to the manufacturer's instructions in G-spin ${ }^{\text {TM }}$ total DNA Purification Kit (Fermentas, EU, 2014).

Reaction mixtures were subjected to the cycling program in a DNA heated lid thermal cycler. The PCR conditions were $95^{\circ} \mathrm{C}$ for 3 $\min , 95^{\circ} \mathrm{C}$ for $2 \mathrm{~min}, 30$ cycles of $\left(94^{\circ} \mathrm{C}\right.$ for 30 
$\mathrm{s}, 50-52^{\circ} \mathrm{C}$ for $30 \mathrm{~s}$ and $72^{\circ} \mathrm{C}$ for $1 \mathrm{~min}$ ) a final step of $72^{\circ} \mathrm{C}$ for $5 \mathrm{~min}$.

Polymerase chain reaction (PCR)
The gel was stained with ethidium bromide and photographed under UV trans-illumination.

products were separated on 3\% agarose gels.

Table (1): Primers used in the multiplex reverse transcriptase polymerase chain reaction.

\begin{tabular}{|c|l|c|}
\hline Gene & \multicolumn{1}{|c|}{ Primer sequence $(\mathbf{5} \rightarrow \mathbf{1}$ ') } & Size (bp) \\
\hline $18-3$ & $\begin{array}{l}\text { F: TCTTTCTCCTTTTGTGTCATGC } \\
\text { R:GTTTCTTGCTAAATAACTAAGCAAGTGAACAGA }\end{array}$ & $281-313$ \\
\hline $4-2$ & $\begin{array}{l}\text { F: AAGCTTCTCTGGCCATTTGA } \\
\text { R: GTTCATAAACTTCAAGCAATGACA }\end{array}$ & $217-248$ \\
\hline $6-7$ & $\begin{array}{l}\text { F: AGTCCACCCAGTGCATTCTC } \\
\text { R: GTTTCTTCATGTGGCTGGTATGCTGTT }\end{array}$ & $333-515$ \\
\hline $9-2$ & $\begin{array}{l}\text { F: GGATTGCCAAGAATTTGAGG } \\
\text { R: GTTTCTTTCCTGAGTTGTGGACAGGGTTA }\end{array}$ & $318-360$ \\
\hline $15-3$ & $\begin{array}{l}\text { F: TCTGGGCGTGTCTGTCATAA } \\
\text { R: GTTTCTTTTCTCAGGGAGGAGTGTGCT }\end{array}$ & $2757-222$ \\
\hline $6-4$ & $\begin{array}{l}\text { F: TTTGCAACAGCTCAGTTTCC } \\
\text { R: GTTTCTTAATCGCTGGCAGATCTTAGG }\end{array}$ & $222-259$ \\
\hline $12-1$ & $\begin{array}{l}\text { F: CAAAATTGTCATTGAACACATGTAA } \\
\text { R:GTTCTTTCAATGGTCAAGAAATACTGAAGTACAA }\end{array}$ & $258-298$ \\
\hline $5-5$ & $\begin{array}{l}\text { F: CGTTTTACCTGGCTGACACA } \\
\text { R: GTTTCTTGGTTTAAAACTCAATACCAAACAA }\end{array}$ & $357-442$ \\
\hline X1 & $\begin{array}{l}\text { F: GGATGGATGGATGGATGAAA } \\
\text { R:GTTCTTAAGGTATATATCAAGATGGCATTATCA }\end{array}$ & \\
\hline
\end{tabular}

\section{RESULTS}

\subsection{Fluorescent microscopic examination}

Stem cells weren't detected in postmortem liver tissue of any mice of group I in all subgroups of group I: group Ia, group $\mathrm{Ib}$ and group Ic $\rightarrow$ percentage $0 \%$ but they were detected postmortem in liver tissue of 30 mice of group II by a percentage of $93.75 \%$ (Figure 1 and Table 2). 


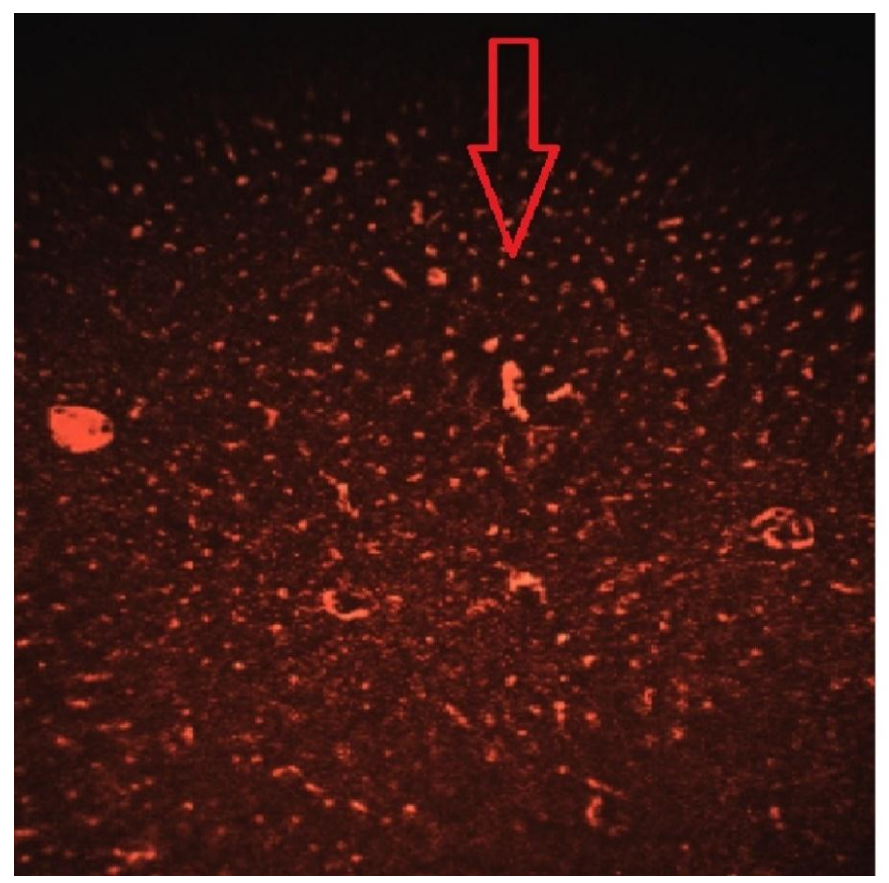

Figure (1): Fluorescent stem cells in postmortem liver tissue (arrow).

Table (2): Comparison of the percentage of fluorescent stem cells presence in postmortem liver tissue in adult mice, $\mathrm{n}=32$.

\begin{tabular}{|c|c|c|c|}
\hline Parameter & $\begin{array}{c}\text { Group I } \\
\text { (Control groups) }\end{array}$ & Group II & $\mathbf{X}^{2}$ \\
\hline $\begin{array}{c}\text { Fluorescent stem cells } \\
\text { percentage }\end{array}$ & $0 \%$ & $93.8 \%$ & $117.55 * * *$ \\
\hline
\end{tabular}

$\mathrm{P}<0.001 * * *$

\subsection{Deoxyribonucleic acid profiling}

There is no detected change in DNA profile in blood samples, hair, buccal swabs and postmortem liver tissue in any mice in group I: Ia, Ib and Ic $\rightarrow$ percentage $0 \%$. The change in DNA profile was detected in 20 mice postmortem in liver tissue samples by a percentage of 62.5\% (Figures 2, 3 and Table 3). 


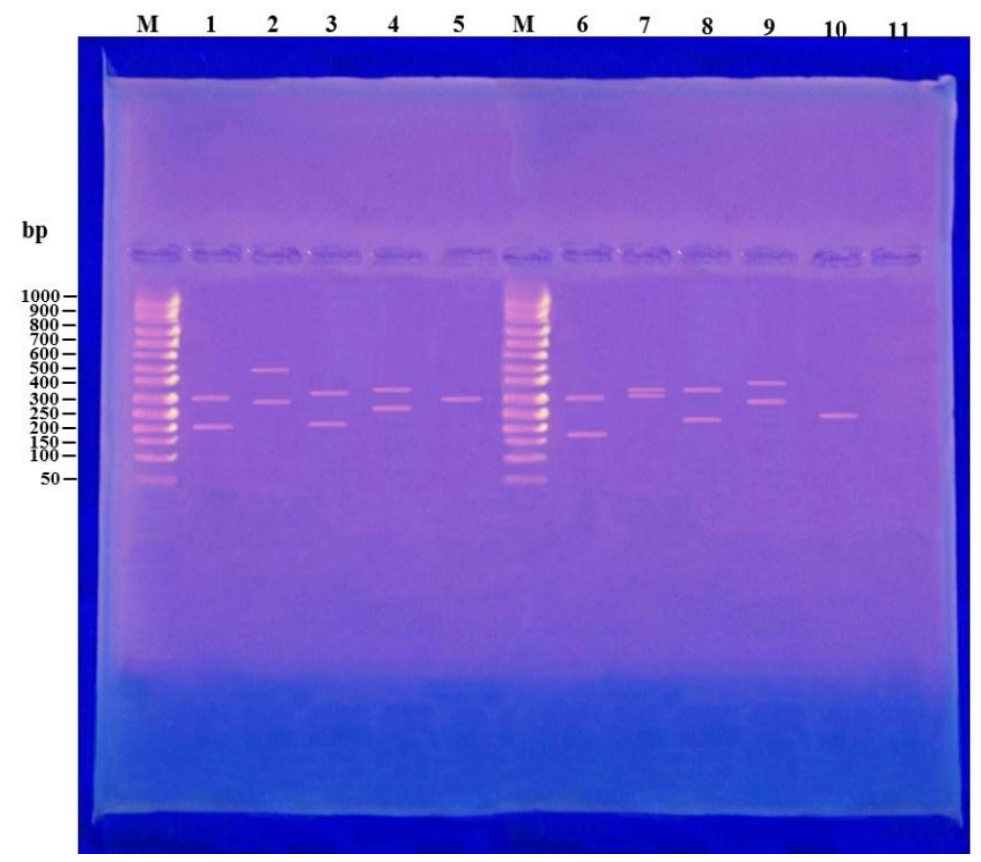

Figure (2): Change in deoxyribonucleic acid profile in postmortem liver tissue samples after hematopoietic stem cell transplantation.

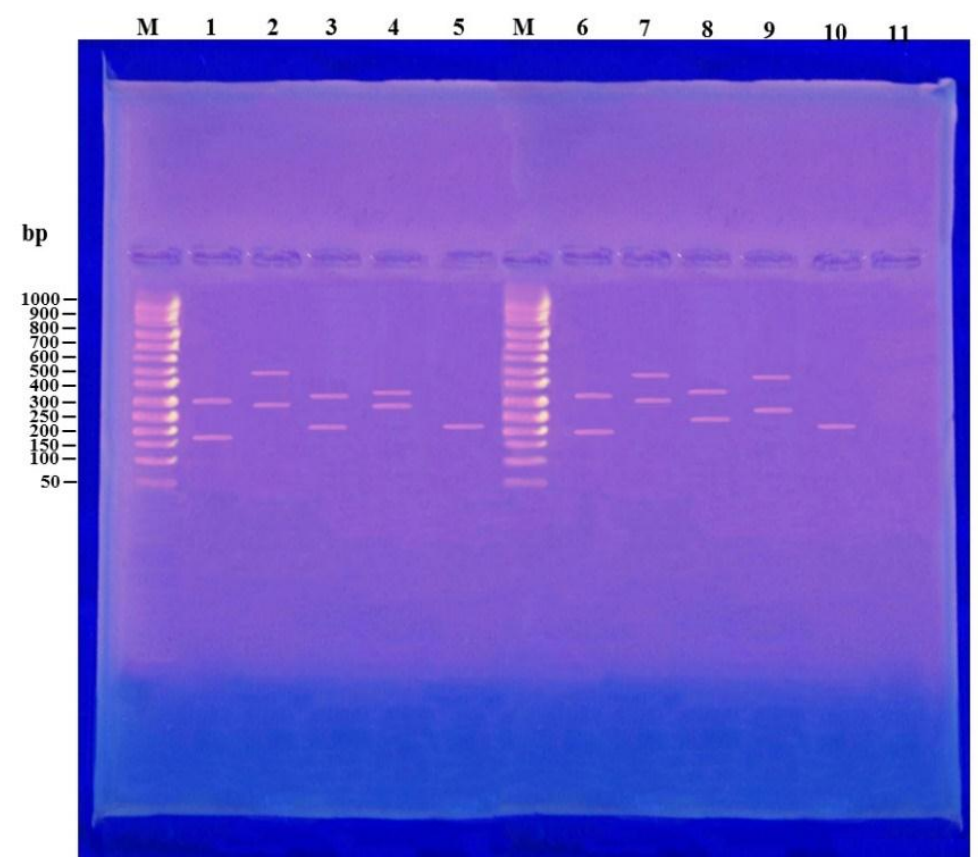

Figure (3): Change in deoxyribonucleic acid profile in postmortem liver tissue after hematopoietic stem cell transplantation. 
Table (3): Comparison of the percentage of DNA profile change in postmortem liver tissue samples in adult mice, $\mathrm{n}=32$ :

\begin{tabular}{|c|c|c|c|}
\hline \multirow{2}{*}{ Parameter } & $\begin{array}{c}\text { Group I (Control } \\
\text { groups) }\end{array}$ & Group II & $\mathbf{X}^{\mathbf{2}}$ \\
\hline Postmortem liver tissue & $0 \%$ & $62.5 \%$ & $71.111 * * *$ \\
\hline
\end{tabular}

$\mathrm{P}<0.001 * * *$

\section{DISCUSSION}

The assumption that all the cells in the human body have the same DNA profile which constitutes the basis for comparative analysis in forensic genetics was discovered to be wrong when tissues of recipients after allogeneic stem cell transplantation are investigated (Dauber et al., 2004; Andréasson et al., 2006).

This work aimed at the postmortem detection of the possible change in DNA fingerprint after allogeneic HSCT in liver tissue samples. Many studies not only confirmed the mobilization and presence of hematopoietic cells in liver tissue after HSCT, but also proved their differentiation into hepatocytes (Jang et al., 2004; Zhan et al., 2006). Abkowitz (2002) revealed donor-derived cells in almost all tissues of recipients after allo-HSCT. They found that human hematopoietic stem cells could become skin, gut, or liver cells. Körbling et al. (2002) examined biopsy specimens from the liver, gastrointestinal tract, and skin were obtained from 12 patients who had undergone transplantation of hematopoietic stem cells and proved showed evidence of complete hematopoietic donor chimerism in biopsy specimens. Santurtún et al. (2017) concluded in their study that whatever the cellular source of HSCT donor's DNA might be, mixed chimerism with both donor's and host's DNA profiles can be detected, and this must be taken into account when performing DNA profiling of cases potentially involving persons who had undergone HSCT.

Mosaad (2014) stated that hematopoietic stem cells are determined travelers. Migration of hematopoietic stem cells through the blood, across the endothelial vasculature to different organs and to bone marrow is termed homing. Donor cells not only can reach liver after hematopoietic stem cell transplantation but also they can transform to hepatocytes (Moon et al., 2009).

\section{CONCLUSION}

Hematopoietic stem cells can be detected postmortem by a percentage of 93.75\% in liver tissue after hematopoietic stem cell transplantation. The change in DNA profile postmortem in liver tissue samples by a percentage of $62.5 \%$.

\section{RECOMMENDATIONS}

As hematopoietic stem cells can be detected in liver tissue after hematopoietic stem cell transplantation, other types of samples have to be studied for this purpose.

\section{REFERENCES}

Abkowitz JL. (2002): Can human hematopoietic stem cells become skin, gut, or liver cells? N Engl J Med; 346: 770-772.

Almeida JL, Hill CR, and Cole KD (2014): Mouse cell line authentication. Cytotechnology; 66(1): 133-147.

Andréasson H, Nilsson M, Budowle B, Lundberg H, Allen M (2006): Nuclear and mitochondrial DNA quantification of various forensic materials. Forensic Sci Int; 164: 56-64. 
Angelis D, Gibelli D, Palazzo E, Sconfienza L, Obertova Z, Cattaneo C (2016): Skeletal idiopathic osteosclerosis helps to perform personal identification of unknown decedents: A novel contribution from anatomical variants through CT scan, Science \& Justice; 56 (4): 260-263.

Chaudhary G, Dogra TD, Raina A (2015): Evaluation of blood, buccal swabs, and hair follicles for DNA profiling technique using STR markers. Croat Med J.; 56(3): 239-245.

Cattaneo C, Porta D, De Angelis D, Gibelli D, Poppa P, Grandi M (2010): Unidentified bodies and human remains: an Italian glimpse through a European problem, Forensic Sci. Int.; 195: 167.

Dauber EM, Dorner G, Mitterbauerb M, Wenda S, Faé I, Glock B, Mayr WR (2004): Discrepant results of samples taken from different tissues of a single individual. International Congress Series (1261): 48-49.

Hong YC, Liu HM, Chen PS, Chen YJ, Lyou JY, Hu HY, Yi MF, Lin JS, Tzeng CH (2007): Hair follicle: a reliable source of recipient origin after allogeneic hematopoietic stem cell transplantation. Bone Marrow Transplant.; 40(9): 871-874.

Jacewicz R, Lewandowski K, Rupa-Matysek J, Jedrzejczyk M, Komarnicki M, Berent J (2013): Genetic investigation of biological materials from patients after stem cell transplantation based on autosomal as well as Y-chromosomal markers. Int $J$ Legal Med.; 127(2): 359-62.

Jang YY, Collector MI, Baylin SB, Diehl AM, Sharkis SJ (2004): Hematopoietic stem cells convert into liver cells within days without fusion.

Nat Cell Biol.; 6(6): 532-539.

Körbling M, Katz RL, Khanna A, Ruifrok AC, Rondon G, Albitar M (2002): Hepatocytes and epithelial cells of donor origin in recipients of peripheral-blood stem cells. N Engl J Med; 346: 738-746.

Li YT, Xie MK and Wu J (2014): DNA profiling in peripheral blood, buccal swabs, hair follicles and semen from a patient following allogeneic hematopoietic stem cells transplantation. Biomed Rep.; 2(6): 804-808.
Milde A, Kühl-Burmeister R, Ritz-Timme S, Kaatsch HJ (1999): DNA typing in cases of blood chimerism. Int J Legal Med; 112(5): 333-5. Moon YJ, Yoon HH, Lee MW, Jang IK, Lee DH, Lee JH, Lee SK, Lee KH, Kim YJ, Eom YW (2009): Multipotent progenitor cells derived from human umbilical cord blood can differentiate into hepatocyte-like cells in a liver injury rat model. Transplantation proceedings; 41 (10): 4357- 4360. Mosaad YM (2014): Hematopoietic stem cells: An overview. Transfusion and apheresis science; 51: 68-82.

Nevozhay D, Opolski A (2006): Key factors in experimental mouse hematopoietic stem cell transplantation. Arch Immunol Ther Exp; 54(4): 253-69.

Parasuraman S, Raveendran R, and Kesavan $\mathbf{R}$ (2010): Blood sample collection in small laboratory animals. J Pharmacol Pharmacother.; 1(2): 87-93.

Picazo MG, García-Olmo DC (2015): DNA from tissues of young mice is optimal for genotyping. Electron. J. Biotechnol.; 18: 83-87.

Santurtún A, Riancho JA, Santurtún M, Richard C, Colorado MM, Unzueta MG, Zarrabeitia MT (2017): Genetic DNA profile in urine and hair follicles from patients who have undergone allogeneic hematopoietic stem cell transplantation, Science \& Justice; 57 (5): 336-340.

Ten Hove WR, Verspaget HW, Barge R, Lamers CB, van Hoek B (2007): Liver Chimerism After Allogeneic Blood Stem Cell Transplantation. Transplantation Proceedings; 39 (1): 231-236.

Zhan Y, Wang Y, Wei L, Chen H, Cong X, Fei R, Gao Y, Liu F (2006): Differentiation of hematopoietic stem cells into hepatocytes in liver fibrosis in rats. Transplant Proc.; 38(9): 3082-3085.

Zhou Y1, Li S, Zhou J, Wang L, Song X, Lu X, Wang J, Ye Y, Ying B, Jia Y (2011): DNA profiling in blood, buccal swabs and hair follicles of patients after allogeneic peripheral blood stem cells transplantation. Leg Med; 13(1): 47-51. 
الكثف بعد الوفاة عن خيمرية الحمض النووى في خلايا الكبد بعد زرع الخلايا الجذعية المكونة للام الخيفى في ذكور الفئران البالغة

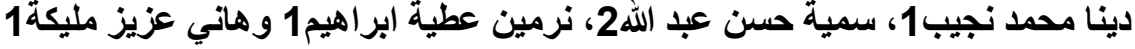

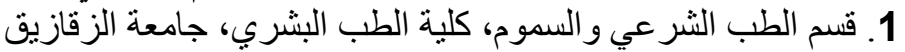

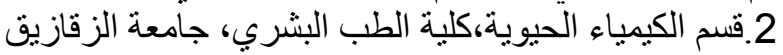

ان الاستعر اف الثخصي بعد الوفاة بعتمد علي استخراج الحمض النووي من البقايا البشرية أو المواد البشرية المختلفة. وقد أثنتت بعض الدر اسات أنه من الممكن أن يوجد اختلاف في تحليل البصمة الوراثية بين أنسجة الجسم المختلفة لنفس الثخص نتيجة الطفرة الور اثثية أو خيميرية الحمض النووي.

هدف الدراسة: كان هدف هذا البحث دراسة احتمال تغيير البصمة الور اثية في عينات الكبد بعد الوفاة بعد زرع الخلايا الجذعية المشكلة للام الخيفي في ذكور الفئر ان البالغة.

الطرق والأدوات: تم اجر اء البحث على 128 من ذكور الفئران البالغة التي يزن كل منها 25 جر ام في قسمى الطب الثرعي و السموم الإكلينيكية و الكيمياء الحيوية (معمل زر اعة الخلايا الجذعية)- كلية الطب- جامعة الزقازيق. تم عمل تحليل البصمة الوراثية من الدم لكل الفئران قبل زر اعة الخلايا الجذعية المشكلة للدم الخيفي وتم اعادته بعد 3 شهور بعد زر اعة الخلايا الجذعية من الكبد لمعرفة مدي التغيير في تحليل البصمة الور اثية.

وقد أظهرت نتائج البحث وجود الخلايا الجذعية المشكلة للام في عينات الكبد بعد الوفاة في 30 فأربنسبة 93.75\% وذللك يؤكد أنها خلايا متحركة تنتقل إلي الأحشاء بعد زراعتها في الدم، كما أظهرت حدوث تغيير في فحص البصمة الوراثية بعد زراعة الخلايا الجذعية المشكلة للام في عينات الكبد بعد الوفاة في 20 فأر بنسبة 62.5\% الاستنتاج: أن خيمرية الحمض النووي وتغيير البصمة الور اثية تحدث بعد زر اعة الخلايا الجذعية المشكلة للدم الخيفي في خلايا الكبد الخاصة بالمريض. التوصيات: يمكن استخدام عينات من الكبد بعد الوفاة كمصدر لعمل البصمة الور اثثة في المرضي الذين يقومون بزراعة الخلايا الجذعية المشكلة للام الخيفي مع ضرورة البحث عن أنواع عينات بيولوجية جديدة لعطل تحليل البصمة الور اثئة 